\title{
CHARACTERIZATION OF CELLULOSE AND CELLULOSE NITRATE NANOFILMS
}

\author{
Mayara Elita Carneiro ${ }^{1 *}$, Marina Stygar Lopes ${ }^{2}$, Anna Luisa Franco Baumel de Andrade ${ }^{3}$, Silvana Nisgoski ${ }^{4}$, \\ Graciela Inês Bolzon de Muniz'; \\ 1 *Federal University of Paraná, Department of Forest Engineering and Technology, Curitiba, Paraná, Brazil - \\ mayaraecarneiro@gmail.com (*) \\ ${ }^{2}$ Federal University of Paraná, PhD student in the Forest Engineering Graduate Program, Curitiba, PR, Brazil - marinastygar@gmail.com \\ ${ }^{3}$ Federal University of Paraná, Course of Industrial Timber Engineering, Curitiba, Paraná, Brazil - isa_dod@ @otmail.com \\ ${ }^{4}$ Federal University of Paraná, Department of Forest Engineering and Technology, Curitiba, Paraná, Brazil - silvana.ufpr@gmail.com \\ ${ }^{5}$ Federal University of Paraná, Department of Forest Engineering and Technology, Curitiba, Paraná, Brazil - gbmunize@ufpr.br
}

Received for publication: 13/12/2017 Accepted for publication: 26/09/2018

\begin{abstract}
The objective of this work was the characterization of cellulose and cellulose nitrate nanofilms from the mixture of Kraft pulps of Pinus sp. and Eucalyptus sp. bleached. The production of nanocellulose was made by mechanical processing. To obtain the cellulose nitrate, the nitration was carried out in part of the produced nanocellulose. The characterizations were performed by means of scanning electron microscopy, medium infrared spectroscopy, tensile strength and absorption assay. The results demonstrate that there was influence of nitration in the characteristics of the films produced. The nanofilms of cellulose nitrate appear more interesting for the absorption property, indicating the use of this process for uses that require this characteristic. Keywords: nanotechnology, nanocellulose, nitration.
\end{abstract}

\section{Resumo}

Caracterização de nanofilmes de celulose e de nitrato de celulose. Este trabalho teve como objetivo a caracterização de filmes nanoestruturados de celulose e de nitrato de celulose a partir da mistura de polpas Kraft de Pinus sp. e Eucalyptus sp. branqueadas. A produção de nanocelulose foi por processamento mecânico. Para obter o nitrato de celulose, foi realizada a nitração em parte da nanocelulose produzida. As caracterizações foram realizadas por meio de microscopia eletrônica de varredura, espectroscopia no infravermelho médio, resistência à tensão e ensaio de absorção. Os resultados demonstram que houve influência da nitração nas características dos filmes produzidos. Os filmes nano de nitrato de celulose mostraram-se superiores para a propriedade de absorção, indicando o uso deste processo para utilizações que demandem essa característica.

Palavras-Chave:nanotecnologia, nanocelulose, nitração.

\section{INTRODUCTION}

Cellulose is the most abundant biopolymer in nature, and it stands out as a renewable, biodegradable, low-cost, low density, high strength, and good mechanical properties (BÖRJESSON; WESTMAN, 2015) material.

In nanotechnology, the obtainment and use of cellulose nanofibers and their applications in composite materials has attracted the attention of researchers because of the favorable combination of high strength and stiffness properties coupled with the fact that it is a hydrophilic, biodegradable, renewable material that provides less environmental impact, making this material promising for commercial use (SIRO; PLACKETT, 2010).

Nanofibrillated cellulose consists of a material obtained by the disintegration of the cellulose subjected to a mechanical process. This process led to an increase in the external surface, allowing a greater area of contact and greater capacity to generate strong hydrogen bonds between the microfibrils of the cell wall, which allows the production of a material with high resistance, being able to be used for coatings or as a reinforcement for applications in various products in the paper industry (BIAO et al., 2011; POTULSKI et al., 2016).

Microfibrillated cellulose (CMF) is the material obtained by mechanical processes with diameters ranging from 25 to $100 \mathrm{~nm}$. Nanofibrillated cellulose (CNF) has diameters ranging from 5 to $30 \mathrm{~nm}$ (SEHAQUI et al., 2011).

Sabo et al. (2015), emphasizes that nanocellulose is derived from natural resources and its potential for enhancement is high enough that there is considerable interest in finding ways to extract it in an economically viable way, and although much recent progress has been made, many challenges for the efficient and economical use of nanocellulose.

Paper quality is related to a number of factors that influence, directly or indirectly, its properties. Recent studies have been carried out to develop new types of papers, based on nanofibrillated cellulose, and are called nanostructured cellulosic films or nanopapers. When comparing conventional paper with nanostructured papers and films, they have higher density, flexibility and better mechanical resistance properties. In addition, the papers

FLORESTA, Curitiba, PR, v. 49, n. 2, p. 219-226, abr/jun 2019. 
produced with nanofibrillated cellulose can be optically transparent, with low coefficient of thermal expansion, low porosity, and also have excellent oxygen barrier properties (NOGI; YANO, 2009; GONZÁLEZ et al., 2012).

Other main application areas for nanocellulose are the food industry, where nanocellulose can form emulsions and dispersions; medical and hygiene products, since the nanocellulose has good absorption properties and can be used, for example, in cosmetics, fabrics or diapers; and in composite materials, since the nanocellulose has unique properties to be used as filler or reinforcement in biocomposites (BÖRJESSON; WESTMAN, 2015).

The abundance of applications and possible variations in the properties of the materials in which the nanofibrillated cellulose is applied justify the increasing interest in studies that provide the knowledge of the main properties and characteristics of this type of nanocellulose (POTULSKI et al., 2016).

Nitrocellulose is a polymer derived from cellulose and, its appearance closely resembles cotton or a slightly yellow or colorless gelatinous liquid with odor of ether. Nitrocellulose is temperature sensitive, slightly hygroscopic, and deteriorates more rapidly in the presence of water. In addition to its technical properties, nitrocellulose has a great sustainable appeal, as its main raw material is cellulose. Besides these characteristics, nitrocellulose presents an extremely versatile resin, which explains its application in several segments (TEMMING et al., 1973).

There are studies that characterize the nanocellulose, produced through the mechanical process, in gel form. Other characterizations are made in films from nanocellulose (POTULSKI et al., 2016). The characterization of these films is based on techniques such as Scanning Electron Microscopy (SEM) and Transmission (MET), methods that allow visualization of the material at nano scale. For the films, it is necessary to evaluate their physical and mechanical properties to indicate the potential of this material (NOGI; YANO, 2009; GONZÁLEZ et al., 2012; POTULSKI et al., 2016).

There are no studies characterizing the mechanically produced nanocellulose and its subsequent nitration. The characterization of nitrated nanocellulose is important due to the demands of certain industries, such as chemistry, that use nitration during its production.

In this context, the objectives of this study was the characterization of nanofilms of cellulose and cellulose nitrate from the mixture of Kraft pulp of Pinus sp. and Eucalyptus sp. bleached, in addition to evaluating the influence of nitration on the characteristics of the nanofilm produced.

\section{MATERIAL AND METHODS}

\section{Collection and production of material}

For the preparation of nanofibrillated cellulose, the industrial Kraft cellulosic pulps of Pinus sp. and Eucalyptus sp. bleached was used. At first the humidity was determined and from this it was possible to calculate the mass of the pulp and the amount of water necessary for the preparation of the material with a consistency of $3 \%$ of the dry mass. The pulp then passed through the mechanical process of fiber disintegration for five minutes, with the aim of promoting the individualization and homogeneity of the same.

The material dispersed in water underwent the mechanical defibrillation process in the Super Masscolloider Masuko Sangyo defibrillator mill using 8 passes and a constant frequency of $1500 \mathrm{rpm}$. After the 8 passes for the defibrillator mill, the gotten nanofibrillated cellulose was destined to the production of films for the characterization and determination of its properties (POTULSKI et al., 2016).

For the production of the cellulose nitrate nanofilms, part of the material obtained underwent the nitration process from the ratio of 3:1 sulfuric / nitric acid (SUN et al., 2010).

A weight of $60 \mathrm{~g} / \mathrm{m}^{2}$ was established for the films. Both films were produced with ten replicates of cellulose and cellulose nitrate nanofilms, totaling twenty films. Based on the determined weight and the humidity of the material, the masses necessary to reach this weight were calculated, considering the area of each film equal to $113 \mathrm{~cm}^{2}$. Production started by depositing the nanofibrillated cellulose onto the filter paper set under a nylon screen where the material was vacuum filtered. Subsequently, the material was moved to the paper forming machine under a temperature of $90^{\circ} \mathrm{C}$ and a constant pressure of $80 \mathrm{KPa}$ for 15-20 minutes. The films were then conditioned in an air-conditioned room with a temperature of $23 \pm 2{ }^{\circ} \mathrm{C}$ and relative humidity of $50 \pm 2 \%$ for further tests and laboratory tests.

\section{Characterization of material}

For the characterization of the films through the scanning electron microscopy technique (SEM) the FEI Quanta 450 FEG Scanning Microscope was used, with a resolution of $1 \mathrm{~nm}$. The material used in the analysis was prepared by the deposition of a small part of the films on a double-sided copper tape adhered to the sample port. This technique allows mapping of surfaces with high resolutions and obtaining micrographs of these surfaces.

For the mid-infrared spectroscopy (FTIR-MID), 5 spectra were obtained for each type of film produced in the medium infrared region, which comprises the spectral region of 500 to $5000 \mathrm{~cm}^{-1}$. The equipment used was 
the Bruker Tensor 37 spectrophotometer with 16 scans and a resolution of $2 \mathrm{~cm}^{-1}$. This technique allows us to observe the main peaks present in the films, besides identifying possible changes in the peak intensities that can be generated by the nitration process.

The tensile strength (Mpa) of the films was determined in a Brookfield CT3 texture analyser using the TA-DGA probe according to the standard method D882-12 (ASTM, 2012). For the tests, rectangular specimens measuring $60 \mathrm{~mm}$ high $\times 25 \mathrm{~mm}$ wide were used. The water absorption by the Cobb method $\left(\mathrm{g} / \mathrm{m}^{2}\right)$, corresponds to the mass of water absorbed by 1 square meter of the film or paper in a certain time interval, in this study the time of 60 seconds was adopted. The method was adapted from the T441 standard of TAPPI (2004).

\section{RESULTS}

\section{Visual characterization}

Figure 1 shows the visual appearance of the films produced, where the cellulose nanofilms (A) are shown to be smooth, while the nanofilms of cellulose nitrate (B) are wrinkled.

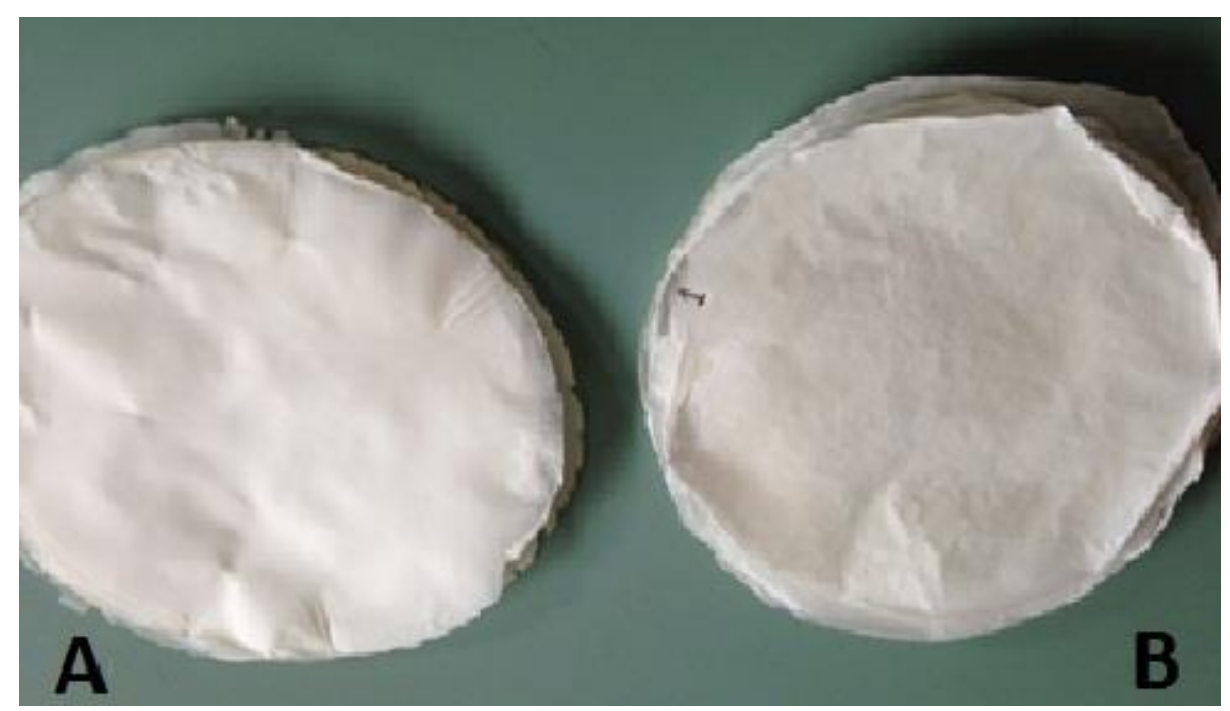

Figure 1. Nanofilms A: Cellulose; B: Cellulose nitrate

Figura 1. Nanofilmes A: Celulose; B: Nitrato de celulose.

Both films produced in this study were transparent, but in cellulose nanofilms this characteristic is more pronounced in relation to cellulose nitrate nanofilms.

\section{Microscopic Characterization}

In Figures 2 and 3, images obtained by Electron Microscopy of Scanning referring to films produced from nanofibrillated cellulose, in magnifications of 1000 and 15000 times.

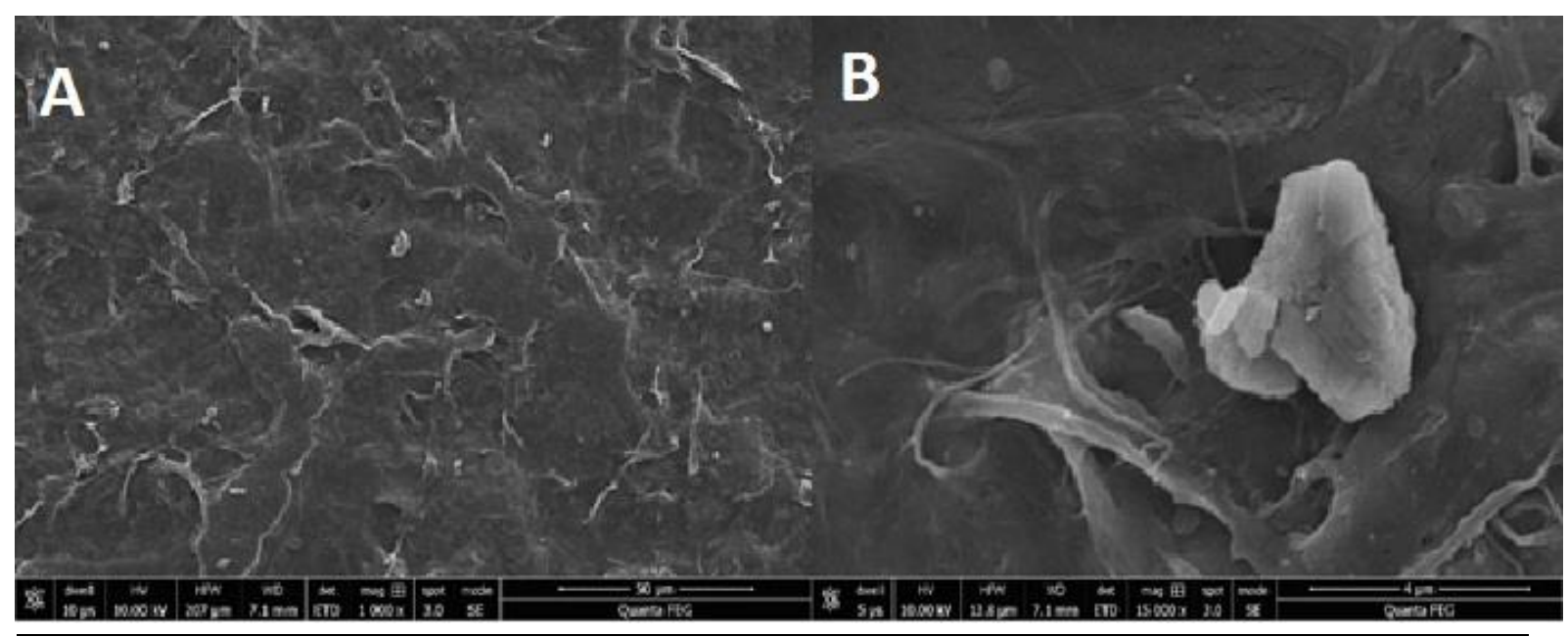

FLORESTA, Curitiba, PR, v. 49, n. 2, p. 219-226, abr/jun 2019.

Carneiro. M. E. et.al.

ISSN eletrônico 1982-4688

DOI: $10.5380 /$ rf.v49 i2.56909 
Figure 2. SEM of cellulose nanofilms. A) 1000x increase - scale: $50 \mu \mathrm{m} \mathrm{B)} \mathrm{15000x} \mathrm{-} \mathrm{scale:} 4 \mu \mathrm{m}$.

Figura 2. MEV de nanofilmes de celulose A) 1000x magnification - scale: $50 \mu \mathrm{m} \mathrm{B}) 15000 \mathrm{x}$ - scale: $4 \mu \mathrm{m}$.

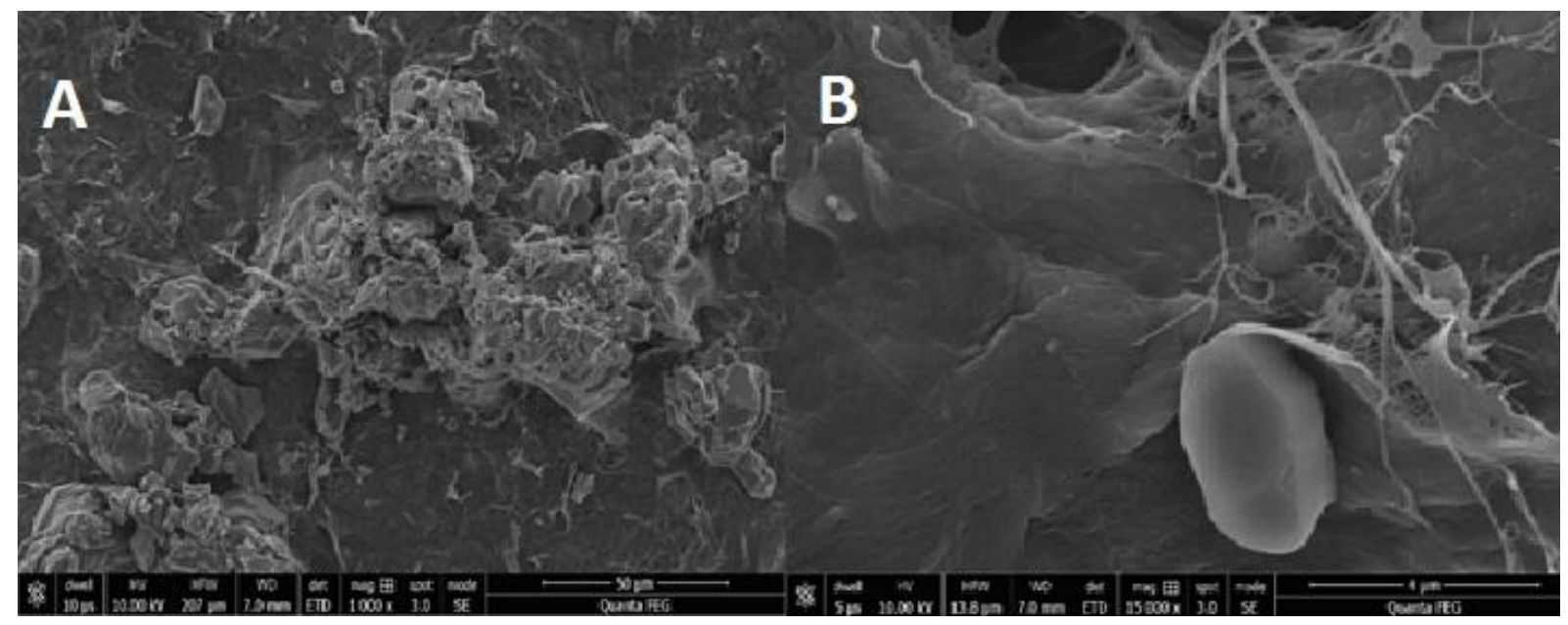

Figure 3. SEM of cellulose nitrate nanofilms. A) 1000x increase - scale: $50 \mu \mathrm{m} \mathrm{B)} \mathrm{15000x} \mathrm{-} \mathrm{scale:} 4 \mu \mathrm{m}$. Figura 3. MEV de nanofilmes de celulose A) 1000x magnification - scale: $50 \mu \mathrm{m} \mathrm{B)} \mathrm{15000x} \mathrm{-} \mathrm{scale:} 4 \mu \mathrm{m}$.

The mechanical defibrillation process resulted in the fibrillation of the cellular wall of the fibers and tracheoids producing nanofibrils, proving that the material produced is a manometric scale material.

\section{Characterization by Medium Infrared Spectroscopy}

The most useful portion for the study of organic molecules is between 500 and $5000 \mathrm{~cm}-{ }^{1}$, called the average infrared. From the FTIR spectrum, it is possible to compare the characteristics of both films produced and to identify the main chemical changes that occurred with nitration in nanofibrillated cellulose.

Next there is the referring specters to nanofilms of celulose (gray) and to nanofilms of cellulose nitrate (red) (Figure 4).

It is observed that, based on the obtained spectra, it is possible to verify bands of common absorption for both samples, however it is possible to observe that the nitration interfered in the spectra and presented distinct peaks in relation to the cellulose nanofilms.

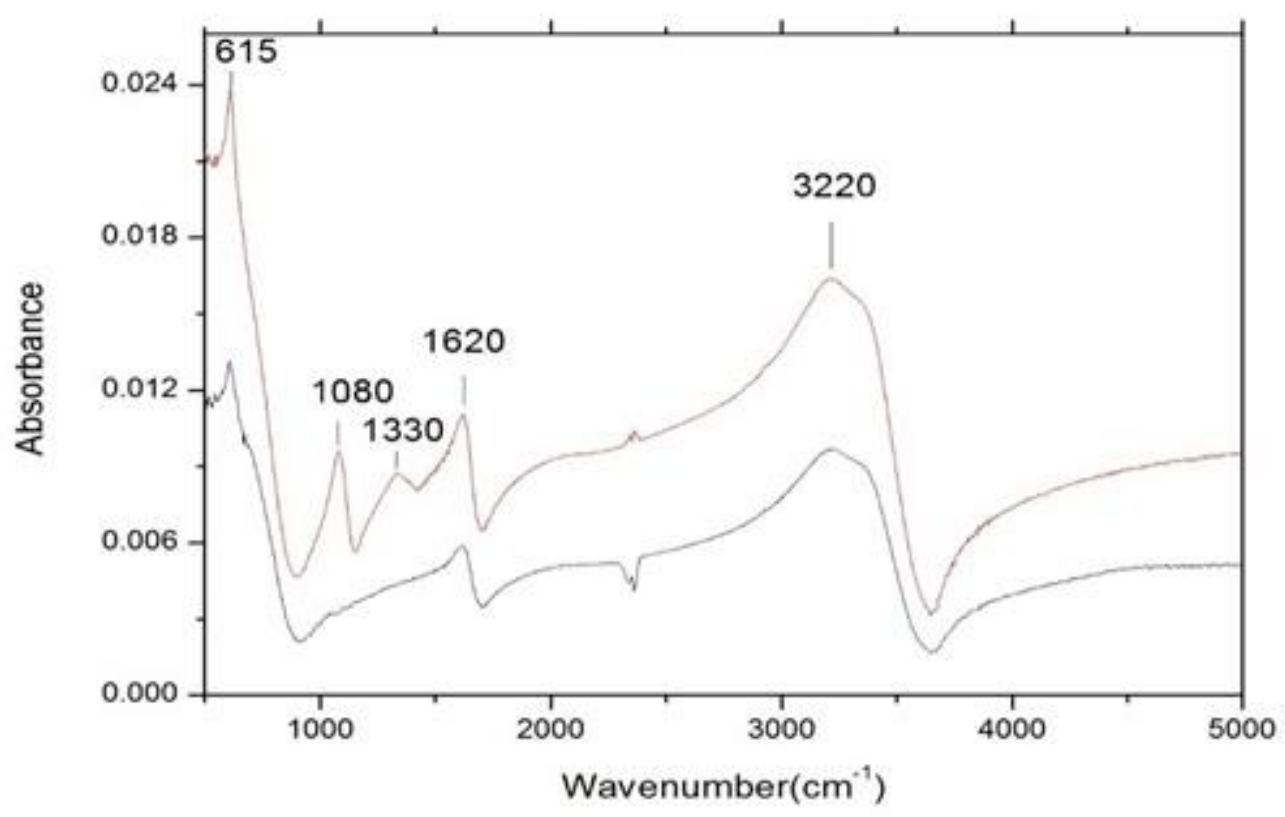

Figure 4. FTIR spectra for cellulose and cellulose nitrate nanofilms. 
Figura 4. Espectros FTIR referentes aos nanofilmes de celulose e de nitrato de celulose.

For both the materials produced in this study it is observed presence of a characteristic peak in $3220 \mathrm{~cm}^{-}$ ${ }^{1}$ attributed to stretching $\mathrm{OH}$ of the cellulose, however with bigger intensity for nanofilms of cellulose nitrate.

Both the produced films had presented peaks accented in the regions of approximately $615 \mathrm{~cm}^{-1}$ and 1620 $\mathrm{cm}^{-1}$ characteristic of the bond $\mathrm{NH}$. However, it is had that for nanofilmes of cellulose nitrate the peaks reveal more accented in relation to nanofilmes of cellulose.

According to the spectra obtained, it is possible to observe a peak, only for cellulose nitrate nanofilms, at $1330 \mathrm{~cm}^{-1}$ assigned to the oxymethyl groups $\left(\mathrm{O}-\mathrm{CH}_{2}\right)$. Regarding cellulose nanofilms, no absorption peak was observed in this region. Another characteristic peak only for cellulose nitrate nanofilms is observed at $1080 \mathrm{~cm}^{-1}$, which refers to the symmetrical stretching of the COC binding characteristic of cellulose.

\section{Mechanical Characterization of Traction Test}

The films were submitted to the tensile strength test and the results pertaining to the different treatments are shown in Table 1.

Table 1. TENSILE STRENGTH TEST (MPA).

Tabela 1. Teste de resistência à tração $(\mathrm{MPa})$.

\begin{tabular}{ccc}
\hline & \multicolumn{2}{c}{ NANOFILMS } \\
\hline & CELLULOSE & CELLULOSE NITRATE \\
\hline Maximum & 10.42 & 5.62 \\
\hline Minimum & 6.1 & 2.06 \\
\hline Medium & 8.46 & 3.72 \\
\hline Coef. Variation & $20.33 \%$ & $27.55 \%$ \\
\hline $\begin{array}{c}\text { Standard } \\
\text { Deviation }\end{array}$ & 1.69 & 1.03 \\
\hline
\end{tabular}

It is observed that the cellulose nanofilms showed higher tensile strength when compared to cellulose nitrate nanofilms, with average values of 8.46 and 3.72 MPa respectively, the values for the standard deviation and coefficient of variation are close to those reported in the literature (HERRERA et al., 2017).

These results indicate that nitration may have modified the cellulose structure and consequently the crystalline packaging, leaving the molecular structure more fragile when submitted to the tensile test, which justifies the significant reduction of the results obtained for the cellulose nitrate nanofilm in cellulose nanofilms for this assay.

\section{Characterization by Absorption Test}

The films were subjected to the Absorption Test and the results are expressed in Table 2.

Table 2. Test of absortion $\left(\mathrm{g} / \mathrm{m}^{2}\right)$.

Tabela 2. Teste de Absorção $\left(\mathrm{g} / \mathrm{m}^{2}\right)$.

\begin{tabular}{ccc}
\hline & \multicolumn{2}{c}{ NANOFILMS } \\
\hline CELLULOSE & CELLULOSE NITRATE \\
\hline Minimum & 0.0317 & 0.0732 \\
\hline Medium & 0.0184 & 0.0061 \\
\hline Coef. Variation & 0.025 & 0.0349 \\
\hline $\begin{array}{c}\text { Standard } \\
\text { Deviation }\end{array}$ & $0.21 \%$ & $0.77 \%$ \\
\hline
\end{tabular}

Nanofilms of cellulose nitrate had presented greater absorption when comparative to nanofilms formed only for cellulose, with 0.025 average values of 0.0349 and $0.025 \mathrm{~g} / \mathrm{m}^{2}$ respectively, the coefficient of variation 
and standard deviation is in accordance with indicated in literature (POTULSKI et al., 2016). In this case, the nitration process resulted in films with wrinkled appearance, which resulted in a higher resistance to absorption.

\section{DISCUSSION}

The wrinkled appearance observed is one of the results of nitration performed on nanofibrillated cellulose. The smooth appearance of the cellulose nanofilms produced are similar to those described by Wang et al. (2013).

To indicate the reduction of fiber diameter caused by the mechanical defibrillation process, it is important to cite the diameter of the tracheoids for Pinus wood and the wood fibers of Eucalyptus of different species found by other authors. The diameter of tracheoids for Pinus wood of different species is, according to literature, on average $40 \mu \mathrm{m}$. Davide and Araújo (1993), in a study with four different Pinus species with an average age of 25 years old, found tracheid diameters varying from 37.25 to $43.63 \mu \mathrm{m}$. In relation to the Eucalyptus, Boschetti et al. (2015), when studying the characteristics of grandis staple fibres wooden of clone of Eucalyptus x Eucalyptus urophylla, had found average values of average diameter of $15 \mu \mathrm{m}$.

Thus, through the SEM images, the width of the tracheids and fibers decreased considerably after the defibrillation process by using the mill. Considering nanostructures as elements that have at least one of their dimensions smaller than $100 \mathrm{~nm}$ (STELTE; SANADI, 2009; QUA; HORNSBY, 2011), it is possible to observe the presence of nanofibrils evaluating Figures 2B and 3B.

In addition, Stelte and Sanadi (2009), comparing scanning electron microscopy images of a coniferous wood (softwood) with a leafy wood (hardwood), concluded that the process of obtaining nanofibrils from the mill presents a lower resistance for long-fiber timbers with lower densities, in addition to being faster and more efficient when compared to woods with short fibre, but in this study a short and long fiber mixture was used, which may lead to different results in comparison to literature. It is also worth noting the importance of studies with these mixtures, since literature is scarce.

In relation to the analysis of spectroscopy in the average infra-red ray, the gotten results are in accordance with other related literatures, as Youssef $e t$ al. (2015) that highlight in their work with nanocellulose the absorption in $1319 \mathrm{~cm}^{-1}$, being this attributed to a more crystalline pattern in the conformation of the oximetilo groups (2 O$\mathrm{CH})$. Pastore et al. (2008) in their work found absorption peaks with average values of $1100 \mathrm{~cm}^{-1}$ characteristic of C-O-C binding. Rodrigues et al. (2016) in their work highlighted absorption peaks between $1633 \mathrm{~cm}^{-1}$ and 702 $\mathrm{cm}^{-1}$ relative to the $\mathrm{NH}_{2}$ bond. Youssef et al. (2015) observed dominant peak at approximately $3300 \mathrm{~cm}^{-1}$, attributed to hydroxyl groups (OH). Still according to Lavoine et al. (2012), the higher contact surface between the nanofibrils provides a greater availability of $\mathrm{OH}$ groups and increases the number of bonds of hydrogen bridges, forming a dense network resulting in greater strength and stiffness to the film.

Mechanical processes such as defibrillation used in this study to obtain nanofibrils, can negatively affect cellulose properties as the number of passes through the mill increases, as there is a gradual decrease in the degree of crystallinity and polymerization. Stelte and Sanadi (2009) point out that the value of the mechanical properties of the cellulose films increases uniformly up to about 10 passes through the mill. Above this number, high shear forces can reduce the length of nanofibrils.

Youssef et al. (2015) when using nanocellulose proceeding from gramineous plant Stipa tenacissima L., pertaining to family Poaceae, with intention to increase the resistance of films, observed that the addition of nanocelulose to the films increased significantly the tensile strenght, when getting the 119,3 values that had varied of 57,2 Mpa in accordance with additional nanocellulose. This significant reinforcement on the properties can be explained by the large surface area as well as the homogeneous dispersion of nanocellulose together with the favorable interactions between the nanocellulose and the polymer matrix to obtain better properties of tensile strength, resulting in mechanically strong and flexible films.

When compared to the literature, both films produced in this study showed lower values in relation to the tensile strength test. This fact is related, in addition to nitration, to the nature of the cellulosic pulp, because in this study the mixture of Pinus and Eucalyptus fibers was used, which certainly interfered in the values of tensile strength, considering that the density, which depends of the fiber and tracheid dimensions, strongly influences the mechanical properties of the films. There is no literature indicating results of films produced with mixed pulps.

The values obtained in this paper for the absorption test are below the values found in literature, such as Potulski et al. (2016), that when producing nano structuralized films of industrial Kraft pulp of Pinus taeda had carried through the absorption assay and had found average values for the different treatments varying from 61.61 to $62.88 \mathrm{~g} / \mathrm{m}^{2}$.

Spence et al. (2010) studied the water retention capacity in nanocellulose films produced from bleached and unbleached pulp of hardwood and longwood. The authors observed that water retention was lower for long fiber films (longwood) compared to short fiber films (hardwood). Therefore, the results obtained are also due to the use of a mixture of industrial Kraft cellulosic pulps of Pinus sp. and Eucalyptus sp. 
Still, according to Sjöström and Alen (1999), factors such as porosity, surface roughness, humid content and hydrophobicity of films or papers can influence the resistance of the films to the penetration of liquids. Another explanation for a lower water absorption may also be related to the increase in density and consequently the reduction of porosity in the films. The very compact structure and lower porosity that the cellulose nanofilms present contribute to the reduction in water penetration (DUFRESNE, 2012).

The literature is scarce in relation to the production and characterization of structured films with nanofibrils of cellulose that underwent nitration. The nitration of the nanostructured cellulose can behave differently, since shorter chain lengths may allow a high degree of nitration. It is recommended to investigate other nitration conditions for the production of these films and to evaluate the thermal stability of this material.

\section{CONCLUSIONS}

- Images obtained by Scanning Electron Microscopy demonstrate that the mechanical defibrillation process resulted in the reduction of the cell wall size of the fibers and tracheoids producing nanoscale material, thus demonstrating the efficiency in the use of the Super Masscolloider Masuko Sangyo defibrillator mill for the production of cellulose nanofibrillation.

- In relation to the analysis of Spectroscopy in the Medium Infrared, similar results were found in the literature, being possible to observe the characteristic peaks of cellulose. In addition, it was possible to identify the major chemical changes that occurred in nitration in nanofibrillated cellulose.

- Nitration, as well as the mixture of short and long fibers, reduced the average values of tensile strength of the films produced. The fact to use a short and long staple fibre mixture also provoked significant reduction of the absorption in comparison to literature, however the results of nanofilmes of cellulose nitrate had revealed more interesting for the absorption property, indicating the use of this process for applications that demand this characteristic.

\section{REFERENCES}

ASTM D882-12. Standard Test Method for Tensile Properties of Thin Plastic Sheeting, 2012.

BIAO, H .; LI-RONG, T .; DA-SONG, D .; WEN, O .; TAO, L .; XUE-RONG, C. Preparation of Nanocellulose with Cation-Exchange Resin Catalysed Hydrolysis. In: Rosario Pignatello. Biomaterials Science and Engineering. Shanghai Intech, 2011; P. 139-152, 2011.

BÖRJESSON, M .; WESTMAN, G. Crystalline Nanocellulose - Preparation, Modification, and Properties. In: Cellulose - Fundamental Aspects and Current Trends. 2015

BOSCHETTI, W .; NETO, T .; PAES, JB; OLIVEIRA, JTS; DUDECKI, L. Anatomical characteristics for the production of wood pulp from eucalypt inclined trees reaction. Brazilian Agricultural Research, v.50, n.6, p. 459-467, 2015.

DAVIDE, LC; ARAÚJO, AJ et al. Characteristics of the Wood and the Needles as a Contribution to the Taxonomic Definition of the Pinus from Tucun Umán. Tree Magazine, Viçosa, v. 7, n.3, p. 5351-357, 1993.

DUFRESNE, A. Nanocellulose: From Nature to High Performance Tailored Materials. Berlin, Walter De Gruyter Incorporated Publishing House, 460 p., 2012.

GONZÁleZ, I .; BOUFI, S .; PÈlACH, MA; ALCALÀ, M .; VILASECA, F .; MUTJÉ, P. Nanofibrillated Cellulose as paper additive in Eucalyptus pulps. Nanocellulose paper additive, Bioresources, v. 7, n. 4. p. 5167 5180, 2012.

HERRERA, MA; MATHEUW, AP; OKSMAN, K. Barrier and mechanical properties of plasticized and crosslinked nanocellulose coatings for paper packaging applications. Cellulose, v. 24, n. 9. p. 3969-3980, 2017.

LAVOINE, N .; DESLOGES, I .; DUFRESNE, A .; BRAS J. Microfibrillated cellulose - Its barrier properties and applications in cellulosic materials: A Review. Carbohydrate Polymers , v. 90, n. 2; p.735-764, 2012.

NOGI, M .; YANO, H. Optically transparent nanofiber sheets by deposition of transparent materials: A concept for a roll-to-roll processing. Applied physics letters, v. 94, p.1-4, 2009.

PASTORE, TCM; OLIVEIRA, CCK; RUBIM, JC; SANTOS, KO Effect of artificial weathering on four tropical woods monitored by infrared spectroscopy (DRIFT). New Chemistry, . 31, n. 8, p. 2071-2075, 2008.

FLORESTA, Curitiba, PR, v. 49, n. 2, p. 219-226, abr/jun 2019.

Carneiro. M. E. et.al.

ISSN eletrônico 1982-4688

DOI: 10.5380/rf.v49 i2.56909 
POTULSKI, DC; VIANA, LC; MUNIZ, GIB; ANDRADE, AS; KLOCK, U. Characterization of nanofilms of nanofibrillated cellulose obtained in different consistencies. Scientia Forestalis, Piracicaba, v. 44, n. 110, p. 361372, 2016.

QUA, EH; HORNSBY, PR Preparation and characterization of nanocellulose reinforcedpolyamide-6. Plastics, Rubber and Composites, v. 40, n. 6/7, p.300-306, 2011.

RODRIGUES, VC; DINIZ, MF; MATTOS, EC; DUTRA, RCL Separation and identification of additives in ink by TLC-IR / UATR and selective extraction. Polymers [online]. v. 26, n.spe; p.68-74, 2016; ISSN 0104-1428. Available At: http://dx.doi.org/10.1590/0104-1428.1887. Accessed on: 13/01/2016

SABO, RC; ELHAJJAR, RF; CLEMONS, CM; PILLAI, KM Characterization and Processing of Nanocellulose Thermosetting Composites. JK Pandey et al. (eds.), Handbook of Polymer Nanocomposites, 1669. Processing, Performance and Application - Volume C: Polymer Nanocomposites of Cellulose Nanoparticles, Springer-Verlag Berlin Heidelberg, 2015. DOI 10,1007 / 978-3-642-45232-1_64.

SEHAQUI, H .; ALLAIS, M .; ZHOU, Q .; BERGLUND, LA Wood cellulose biocomposites with structures at micro- and nanoscale. Composites Science and Technology, V. 71, n. 3, p. 382-387, 2011.

SIRÓ, I .; PLACKETT, D. Microfibrillated cellulose and new nanocomposite materials: a review. Cellulose, v.17, n. 3, p.459-494, 2010.

SJOSTROM, E ; ALEN, R. Analytical methods in wood chemistry, pulping, and papermaking. Springer series in wood science. Berlin: Springer, 316 p., 1999.

SPENCE, KL; VENDITTI, RA; ROJAS, O .; HABIBI, Y .; PAWLAK, J. The effect of chemical composition on microfibrillar cellulose films from wood pulps: water interactions and physical properties for packaging applications. Cellulose, v. 117, p. 835-848, 2010.

STELTE, W ; SANADI, AR Preparation and Characterization of Cellulose Nanofibers from Two Commercial Hardwood and Softwood Pulps. Industrial \& Engineering Chemistry Research, v. 48, p.11211-11219, 2009.

SUN, DP; MA, B .; ZHU, CL; LIU, CS; YANG, JZ Novel Nitrocellulose Made from Bacterial Cellulose. Journal of Energetic Materials, v. 28, n. 2, p. 85-97, 2010.

TECHNICAL ASSOCIATION OF THE PULP AND PAPER INDUSTRY- TAPPI. T441om-98. Water absorbability of sized (non-bibulous) paper, paperboard, and corrugated fiberboard (Cobb test). In: Tappi Test Methods. TAPPI Press, Norcross, GA, 2004.

TEMMING, H .; GRUNERT, H .; HUCKFELDT, H. Linters: Technical Information on Cotton Cellulose. English Translation of the 2 ed. Revised and Augmented German Edition. 1973

YOUSSEF, B .; SOUMIA, A ; MOUNIR, EA; OMAR, C .; ABDELAZIZ, L ; MEHDI, EB; MOHAMED, Z. Preparation and Properties of Bionanocomposite Films Reinforced with Nanocellulose Isolated from Moroccan Alfa Fibers. AUTEX Research Journal, v.15, n. 3, 2015. DOI: 10.1515 / aut-2015-0011 (C) AUTEX.

WANG, H .; LI, D ; ZHANG, R. Preparation of Ultralong Cellulose Nanofibers and Optically Transparent Nanopapers Derived from Waste Corrugated Paper Pulp. Bioresources, v. 8, n. 1, p. 1374-1384, 2013. 